\title{
Attribution and Motivation: Gender, Ethnicity, and Religion Differences among Indonesian University Students
}

\author{
Novita W. Sutantoputri ${ }^{1} \&$ Helen M. G. Watt ${ }^{1}$ \\ ${ }^{1}$ Monash University, Australia \\ Correspondence: Novita W. Sutantoputri, Monash University, Australia. E-mail: Novita.Sutantoputri@gmail.com \\ Received: September 21, 2012 \\ Accepted: December 3, $2012 \quad$ Online Published: December 17, 2012 \\ doi: $10.5430 /$ ijhe.v2n1p12 \\ URL: http://dx.doi.org/10.5430/ijhe.v2n1p12
}

This article was supported by a Postgraduate Publication Award from Monash Research Graduate School, Monash University, Australia.

\begin{abstract}
The study explores the possibilities of gender, ethnicity, and religion differences on attributions (locus of control, stability, personal and external control), motivational goals (learning, performance approach, performance avoidance, and work avoidance), self-efficacy, intelligence beliefs, religiosity, racial/ethnic identity, and academic performance (mid-term test, final test, and GPA scores) within the Indonesian university settings. Racial/ethnic identity had three dimensions: private regard, ethnic importance, and social embeddedness; whilst religiosity had two dimensions: religious behaviour and intrinsic religiosity. 1,006 students (73.8\% Native Indonesians and 24.8\% Chinese Indonesians) from three public and two private universities participated. Males were significantly higher on work avoidance goals. Ethnic and religion differences were found on religiosity: Native Indonesians and Hindus reported higher intrinsic religiosity; Christians reported greater behavioural religiousity. Gender and religion interactions revealed lower locus of control among male Chinese, and lower final test score among male Muslim. Explanations for these differences are advanced and directions for further research outlined.
\end{abstract}

Keywords: Attribution, Motivational goals, Gender, Ethnicity, Religion

\section{Introduction}

Culture, a shared set of core values that regulate behaviour in a certain society (Triandis, 1995) can motivate one to act in a certain way (Scharwtz, 2006). In a society where someone is encouraged to put him/herself before the group (individualistic culture), one would expect individuals to be concerned with thinking well of themselves. In collectivistic cultures, one is expected to consider oneself as interdependent with other members of society and, to put the welfare of the group before oneself (Triandis, 1995). Thus, individual goals and attitudes are encouraged in individualistic cultures, whereas in collectivistic cultures one's personal goals may be subordinated to the goals of one's group (Triandis, 1995). Previous studies have indeed shown cultural differences on motivation (Witkow \& Fuligni, 2007; Woodrow \& Chapman, 2002) and attribution (Anderson \& Butzin, 1974; English \& Chen, 2007; Yan \& Gaier, 1994).

The present study examined cultural differences within the Indonesian context. Three salient cultural factors were explored: gender, religion, and ethnicity. Indonesia, a multi-ethnic country, commonly classifies the people into Native and non-Native, of whom Chinese Indonesians are the biggest minority. In fact, when referring to non-Native it usually means Chinese Indonesians. The relationships between the two ethnic groups is not easy to describe, in fact as recently as 1998 there was a racial riot, in which Chinese Indonesians were victims of looting, killing, and mass raping of women (Blackburn, 2009; Coomaraswamy, 1999; Jusuf, Timbul, Gultom, \& Frishka, 2008). The riot in 1998 was not an isolated case, of which there have been several (Jusuf et al., 2008). Both Native and Chinese Indonesians may further classify themselves into sub-ethnic groups. The Natives may classify themselves such as Javenese, Balinese or Bataknese, which usually relates to the place they or their ancestors were born and raised. The Chinese Indonesians classify themselves as either babah or totok (Ong, 2005). Babah are Chinese Indonesians whose ancestors married Natives, later on their descendants intermarried within the Babah sub-ethnic group or with others of Chinese descent; whereas Totok are Chinese Indonesians who do not have Native ancestors within the family. Both Babah and Totok perceive themselves as of Chinese descent. Due to historical background, Natives are usually 
Muslim, whereas the Chinese Indonesians are Buddhist or Christian (Ananta, Arifin, \& Bachtiar, 2008; Mackie, 2005).

The issue of race even permeates the educational setting, where it is common to find mostly Native Indonesian students in public, and Chinese Indonesians in private universities. As the largest Muslim nation in the world, the State and Islam have reinforced each other in promoting a patriarchal perspective on gender and sexuality (Blackburn, 2004; Clark, 2010). Due to the complexities of interwoven ethnic, religious and gender issues in Indonesia, differences in Indonesian students' attribution and motivation were expected. For example, females were expected to have external locus of control, stable, and uncontrollable attributions due to their living in a patriarchal and heavily religious society. There have not been many studies regarding Native vs. Chinese Indonesian students' motivations and attributions, and how these may intersect with other cultural dimensions which were our interest to explore. Related variables we included were self-efficacy, intelligence beliefs, along with academic performance (mid-term and final test scores, grade point average).

\subsection{Attribution}

People are motivated to understand and master their environments and themselves, in order to make their world more predictable (Pintrich \& Schunk, 2002). This also applies in academic settings where students make attributions about their success and failure, which can be powerful determinants of long-term achievement (Dweck, Goetz, \& Strauss, 1980), and affect students' performance anxiety (Arkin \& Maruyaman, 1979). In general, students make causal attributions for their academic success and failure to ability, effort, task difficulty, and luck (Weiner, 1979). These four reasons can be classified along three dimensions: locus of control (internal or external), stability (stable or unstable), and controllability (controllable or uncontrollable; Weiner, 1985). External locus of control refers to circumstances which are outside, and internal locus to circumstances which are inside, students' control. For example, attributing a bad result to lack of effort constitutes an internal locus of control, whereas attribution of failure to the bad mood of the teacher is an external locus of control. "Stability" refers to whether the causes are considered as something stable (e.g., task difficulty) or unstable (e.g., luck). "Controllability" refers to whether one perceives the causes as controllable or uncontrollable by oneself. One's interpretation of performance success or failure can produce different motivational goals (Dweck, 1975). Students who perceive their failure to be caused by unstable and controllable factors such as lack of effort, were more likely to try to attain mastery. Students who attribute their failures to stable and uncontrollable factors, such as lack of ability (in particular, if they believe that their intelligence is fixed), are more likely to lean toward learned helplessness (Diener \& Dweck, 1978; Dweck, 1975).

\subsection{Achievement Goal Theory}

Achievement goal motivation defines goals as the cognitive representations of the different purposes which students adopt in achievement situations (Urdan \& Maehr, 1995). Students are motivated to develop, attain, or demonstrate competence at an activity (Dweck, 1986); these goal orientations are significant predictors of cognitive, behavioural, and affective outcomes (Ames, 1994; Elliot \& Dweck, 1988). Achievement goal motivations were first classified into learning vs. performance goals (Dweck \& Legget, 1988). Performance goals are further classified into performance approach (to demonstrate competence) vs. avoidance goals (to hide incompetence; Elliot, 1999; Elliot \& Harackiewicz, 1996). Work avoidance goal is another type of motivation explored in the present study, which refers to aiming to get by doing as little work as possible.

Learning goal. Students who hold a learning goal strive to develop their competence and task mastery. The measurement of success for students with a learning goal orientation would be the improvement of their competence and understanding (Butler, 1989). This goal has been found to encourage high level engagement in learning (Ames, 1992) and more active engagement (Meece, Blumenfeld, \& Hoyle, 1988), as well as students' effort (Meece \& Holt, 1993) and persistence (Pintrich \& Schrauben, 1992).

Performance approach goal. Students who have a performance approach goal want to perform well in order to demonstrate their competence (Elliot \& Church, 1997; Elliot \& Harackiewicz, 1996). Similar to learning goals, performance approach goals also relate to persistence and effort (Elliot, McGregor, \& Gable, 1999). Students with a performance approach goal have been found to invest considerable effort to outperform others (Wolters, Yu, \& Pintrich, 1996).

Performance avoidance goal. Students with performance avoidance goals try to protect themselves from the perception that they are not competent (Elliot \& Church, 1997; Elliot \& Harackiewicz, 1996). These goals have been repeatedly identified as maladaptive in previous Western studies, predicting poorer examination performance (Elliot, 
McGregor, \& Gable, 1999), negative affect, and low self-efficacy (Smith, Sinclair, \& Chapman, 2002). These students are also more likely to engage in self-handicapping strategies (Urdan, 2004).

Work avoidance goal. Students with a work avoidance goal motivation use low-effort to no-effort when facing a task, minimising any effort required (Archer, 1994; Dowson \& McInerney, 2001). In contrast to performance avoidant students who may employ low-effort strategies in order to avoid looking incompetent, for these students their lack of effort is not aimed at concealing a lack of ability (Archer, 1994), but their way of expressing negative attitudes toward schoolwork, coping with the constraints and demands of the learning situation (Meece, Blumenfeld, \& Hoyle, 1988), or their interests lie in other areas (Archer, 1994).

\subsection{Self-efficacy and Motivation}

Self-efficacy refers to students' beliefs about whether they possess the skills or abilities required to successfully compete particular tasks. Self-efficacy is related positively to learning and performance approach goals, and negatively to performance avoidance goals (Bong, 2001; Elliot \& Church, 1997). Self-efficacy also predicts students' academic choices and participation (Hackett, Betz, Casas, \& Rocha-Singh, 1992). Gender differences have been consistently identified in particular domains. For example, boys have higher self-perceptions in mathematics (Watt, 2004; Wigfield, Eccles, \& Pintrich, 1996) and sports (Fredricks \& Eccles, 2002); whereas girls have higher self-efficacy in domains which are stereotypically feminine such as reading and English (Jacobs, Lanza, Osgood, Eccles, \& Wigfield, 2002). Gender interactions with ethnic differences have also been identified in general self-efficacy: among African Americans females had higher self-efficacy than males; whereas for Caucasian Americans males had higher self-efficacy than females (Buchanan \& Selmon, 2008).

\subsection{Intelligence Beliefs}

Students' beliefs about their intelligence can affect their motivation (Dweck, 1986). Students who hold an "entity theory" believe that their intelligence is a fixed trait which cannot be developed, and is uncontrollable and stable. Those with an "incremental theory" believe their intelligence can be developed, and controllable and unstable. Which theory students hold thus influences their adoption of motivational goals. Those with entity beliefs are more oriented toward performance goals, and those with incremental beliefs are more oriented toward learning goals (Hong, Chiu, Dweck, Derrick, \& Wan, 1999).

\subsection{Racial/Ethnic Identity}

Strong identification with one's ethnic group has implication for motivation, academic achievement, and academic self-concept (Oyserman, Harrison, \& Bybee, 2001). Being identified with a particular ethnic group can have negative effects when it comes with negative stereotypes (Steele \& Aronson, 1995), or can have positive effects otherwise. Four dimensions of racial/ethnic identity were explored in this study: perceived similarity, private regard, explicit importance, and social embeddedness (Ashmore, Deaux, \& McLaughlin-Volpe, 2004). Perceived similarity refers to one's subjective assessment of the degree to which s/he is a prototypical member of the self-categorised group; private regard refers to favourability judgments about one's racial/ethnic identities. Explicit importance is the individual's subjective appraisal of the degree to which a collective (racial/ethnic) identity is important to overall sense of self; social embeddedness refers to the degree to which one's collective identity is embedded in one's everyday ongoing, social relationships. Social embeddedness has been found to promote good academic results among Vietnamese-American adolescents who did better in school than those who identified with the mainstream American youth culture (Banskton \& Zhou, 1997).

\subsection{Religiosity}

Religiosity refers to behaviour, emotions, and thoughts which are derived from beliefs about the sacred, associated with a particular religious tradition (Dedert, Studts, Weissbecker, Salmon, Banis, \& Septhon, 2004). One religion may have a higher level of devotion to a Divine being than another (Cohen, Sieger, \& Rozin, 2003), which could lead to different kinds of attributions (Young, Morris, Burrus, Krishnan, \& Regmi, 2005). As religion is considered very important in Indonesia, as seen in the compulsory acknowledgement of one's religious affiliation on the national identity card, religiosity was included in this study, measured by three dimensions (Koenig, Meador, \& Parkerson, 1997): organisational, non-organisational, and intrinsic. Organisational religiosity refers to overt behaviour such as going to church, mosque, or temple; non-organisational refers to private religious experience such as praying and reading one's holy book; intrinsic refers to the application of one's religious beliefs and experiences into daily life. 


\section{Method}

2.1 Sample and Participants. Participants were 1006 students from three public and two private universities in Indonesia. The proportions of Chinese Indonesians in the public universities were $2.7 \%, 2.0 \%$, and $1.6 \%$. Proportions of Native Indonesians in the private universities were $24.0 \%$ and $28.7 \%$. Across the sample:

- $73.8 \%$ were Native Indonesians, $24.8 \%$ Chinese Indonesians, $1.6 \%$ "Other" ethnic groups;

- $43.7 \%$ males and $56.3 \%$ females;

- 653 were Muslim, 171 Christian, 105 Catholic, 60 Buddhist, 10 Hindu, and 4 "Other";

- most Native Indonesians were Muslim (86.8\%), 8.3\% Christian, 3.6\% Catholic, 0.1\% Buddhist, and 1.2\% Hindu;

- most Chinese Indonesian participants were Christian (41\%) or Catholic (31.0\%), and 23.6\% were Buddhist.

2.2 Procedure and Data Analysis. Data were collected using paper self-report surveys in 2009, during negotiated classtime at each university. The differences among gender, ethnic, and religious groups were analysed in separate MANOVAs. Interaction effects were tested separately for each of: (i) gender and ethnicity, and (ii) gender and religion, due to their high collinearity. In view of the sample size, statistical significant was set at $p<.01$.

\subsection{Instrumentation}

2.3.1 Attribution. The Revised Casual Dimension Scale (McAuley, Duncan, \& Russell, 1992) was used to measure students' attributions. The scale had 4 subscales: locus, stability, personal control, and external control. Each subscale had 3 items rated from $1=$ the least likely to $9=$ the most likely. Due to low loading, item 1 from the locus of control dimension was dropped, which increased the reliability coefficient alpha for the dimension from .64 to .69. Stability $(\alpha=.74)$, personal control $(\alpha=.58)$, and external control $(\alpha=.75)$ dimensions retained their respective items. Although the reliability coefficient for personal control was below the generally accepted cut-off of approximately 0.70 , it could not be improved by the omission of any items. Other subscales showed acceptable reliability.

2.3.2 Motivational Goals and Self-Efficacy. Motivational goals and self-efficacy subscales were rated from $1=$ not at all true of me to $7=$ very true of me. Learning and work avoidance goals were measured using a scale by Harackiewicz, Durik, Barron, Linnenbrink-Garcia, and Tauer (2008). The learning goals subscale had 7 items $(\alpha$ $=.85)$ and work avoidance goals subscale had 3 items $(\alpha=.86)$. The performance approach goals subscale had 5 items $(\alpha=.89)$ from the Patterns of Adaptive Learning Scales (PALS: Midgley, Maehr, Hruda, Anderman, Anderman, Freeman, Gheen, Kaplan, Kumar, Middleton, Nelson, Roeser, \& Urdan, 2000). Performance avoidance goals had a total of 6 items $(\alpha=.83)$, consisting of 2 items from Harackiewicz et al. (2008) and 4 items from PALS (Midgley et al., 2000).

2.3.3 Theories of Intelligence. Students' intelligence beliefs were measured using Dweck's theories of intelligence scale (rated from $1=$ strongly agree to $7=$ strongly disagree). It had 4 items with $\alpha=.79$.

2.3.4 Racial/Ethnic Identity. A racial/ethnic identity scale from Peck, Brodish, Malanchuk, and Eccles' work (2008) was used to measure students' ethnic identity, tapping $4 \mathrm{racial} /$ ethnic identity dimensions. The Private regard dimension had 4 items $(\alpha=.69)$; Social embeddedness had 2 items $(\alpha=.63)$; and (based on the factor analysis) the remaining factors combined into a new named dimension, Ethnic Importance, with 3 items $(\alpha=.70)$.

2.3.5 Religiosity. Students' religiosity was measured using the Duke University Religion Index (DUREL; Koening, Meador, \& Parkerson, 1997). Based on factor analysis, items for organisational and non-organisational religiosity were combined and named Religious behaviour, although with marginal reliability ( 2 items; $\alpha=.56$ ). Intrinsic religiosity retained its 3 items $(\alpha=.76)$. Table 1 shows sample items for all subscales.

2.3.6 Academic Performance. Students' academic performance was measured using mid-term and final test scores, also their grade point average for the term when data were collected.

\section{Results}

\subsection{Gender Main Effects.}

There were no significant main effects of gender on students' attributions, learning goals, performance approach or avoidance goals, self-efficacy, intelligence beliefs, religiosity, racial/ethnic identity nor academic performance. However, there was one significant gender difference on work avoidance goals, $F(1,976)=9.11, p<.01$, on which males scored higher $(M=3.21, S D=.24)$ than females $(M=2.51, S D=.23)$. 


\subsection{Ethnicity Main Effects.}

There was a main effect of ethnicity on only one variable: intrinsic religiosity, $F(2,976)=14.13, p<.01$. Native Indonesian participants had higher intrinsic religiosity $(\mathrm{M}=3.62, \mathrm{SD}=.05)$ than Chinese Indonesians $(M=3.29, S D$ $=.05)$, or students from "Other" ethnic groups $(M=2.96, \mathrm{SD}=.11)$.

\subsection{Religion Main Effects.}

Significant main effects of religion were found on both the religious behaviour and intrinsic religiosity factors: Christians had the highest religious behaviour $(M=3.66, S D=.06)$ and Buddhists the lowest $(M=2.47, S D=.10)$; Hindus had the highest intrinsic religiosity $(M=3.70, S D=.12)$, and participants with "Other" beliefs the lowest $(M$ $=2.80, S D=.20$ ).

\subsection{Interaction Effects.}

Three significant interaction effects were identified on the factors: locus of control $F(5,976)=3.36, p<.01$; intrinsic religiosity $F(5,976)=11.41, p<.01$; and final test score $F(5,976)=3.07, p<.01$.

- Male Chinese Indonesians had the lowest locus of control attributions $(M=4.20, S D=.24)$, and females from "Other" ethnic groups had the highest $(M=5.05, S D=5.29)$.

- Female Native Indonesians had the highest intrinsic religiosity $(M=3.64, S D=.08)$ and females with "Other" beliefs the lowest $(M=2.82, S D=.17)$.

- Male Muslims had the lowest final test scores $(M=52.69, S D=.53)$ and males with "Other" beliefs the highest $(M=$ $91, S D=9.17)$.

\section{Discussion}

Males had higher work avoidance goals than females in this study, which deliberately limit engagement in learning, perhaps because their interests lay in areas outside the classroom (Archer, 1994) such as being popular. Students who engage in self-handicapping strategies have been found to have an avoidance temperament (Elliot \& Church, 2003); it could be that the Indonesian students' adoption of avoidance goals could be a kind of defence mechanism to protect themselves brought by the pressure of being male in a patriarchal society. A closer look into the relationships between work avoidance goals, self-handicapping, and additional cultural factors could further examine the relationship of gender with work avoidance goals.

Significant differences were found between the religious groups on both their religious behaviour and intrinsic religiosity, which was not too surprising since different religions have different beliefs and practices (Cohen, Sieger, \& Rozin, 2003). Christians scored highest on religious behaviour, and Buddhists lowest. The religiosity scale was developed for Christians in the U.S. and could therefore unintentionally be biased against the other religions (Islam, Buddhism, Hinduism, and "Other") in Indonesia. Unlike Christians who consider attending church services as important, Buddhists do not put a lot of emphasis on ritualistic behaviour such as attending the temple (Smart, 1998), which could explain their lower scores. Hindus had the highest intrinsic religiosity, who put emphasis on practising dharma and karma in their life, from the belief that their actions will have consequences not only in the present, but in the after-life (reincarnation can happen many times and to different forms of life; Venkatachari, 1996).

It was interesting that there were no main effects of ethnicity or religious affiliations on attributional dimensions. It was expected that Chinese Indonesians would be more likely to have external locus of control and uncontrollable attributions due to being victimised in several riots. That Native and Chinese Indonesians did not consistently differ on their attributions could relate to the common segregation schooling for the two groups in Indonesia, in which Chinese Indonesians mostly prefer private school systems from kindergarten to university. This segregation is a remnant of the Dutch colonial schooling system, where there were three kinds of school: Europeesch Lague Schools for the European and upper class Chinese and Natives, Hollandsch-Inlandsche Schools (HIS) for the Natives, and Hollandsch-Chineesche Schools (HCS) for the Chinese (Ong, 2005). Although this segregated system was abolished after Indonesia's independence in 1945, its effects remain. The common practice of Native Indonesians choosing public schooling and Chinese Indonesians private schooling could be due to the complex relationships between the two groups, whereby each may feel safer and more comfortable among their own ethnic group. Thus, they might not experience discreet or indiscreet racial treatment to affect their attributions in academic settings. If the measurement of attributions were linked to racial issues, perhaps the results might be different. That said, male Chinese students exhibited the lowest scores on locus of control, illustrating the complex interrelationships among ethnicity and gender in Indonesia.

It was expected that in a heavily religious and patriarchal society such as Indonesia that females might be more likely to have external locus of control attributions. So, it was quite intriguing that female participants who held "Other" 
religious beliefs had the highest internal locus of control attributions. This might be due to the double pressures (gender and religion) they experience. Being female in a patriarchal and conservatively religious society might make Indonesian women want to be in control of their own lives. Women from cultures which have seen social movements toward gender equality might be more likely to reject traditional females roles, and respond in non-traditional ways (Cialdini et al., 1998). Female participants in this study were university students in the era of internet and globalisation, and had the advantage of studying a higher degree and being exposed to many and new progressive ideas. Another possibility could be that, although female students might still feel limited by social and religious norms and rules, they might want to have control over their lives in the way society allowed and approved. One way would be in academic settings, as being a good student would make one's parents and family proud. Thus, they may feel safe and sure about themselves in an academic setting, which could also account for their having lower work avoidance goals than males. As they were also found to have higher intrinsic religiosity, it could be that instead of rejecting socially imposed gender stereotypes, and norms of women such as devout women are highly valued, they might have accepted them. That gender and religion interactions showed significant differences on academic performance, i.e. final test score, imply that there is more to be explored about the connections between gender and religion in the Indonesian context. We have previously documented (Sutantoputri \& Watt, 2012) that religiosity can be a better predictor for motivational goals than attributions in the Indonesian university context. To be a university student in Indonesia, especially in a private university, requires financial means which consequently implicates socioeconomic status into the interrelationships among religion, ethnicity and university setting.

\section{Conclusion}

In this study within the Indonesian context, there were no main effects of gender, ethnicity, or religious group on attributions, learning goals, performance approach or avoidance goals, self-efficacy, intelligence beliefs, or academic performance. All effects involving race and ethnicity on those outcomes were interaction effects, such as male Chinese having the lowest locus of control, illustrating the interwoven nature of these cultural aspects. The findings of this study give insights into cultural differences and show that, for the Indonesian context, religion seems a very important aspect even in academic settings. Also, the complex of ethnic, religious, gender and economic issues in Indonesia needs to be taken into account. Further differentiation of religious and ethnic cultural affiliations may give more nuanced and valuable further insights into how they shape students' attributions and motivations.

\section{References}

Ames, C. (1992). Classrooms: Goals, structures, and student motivation. Educational Psychology, 84(3), 261-271. http://dx.doi.org/10.1037/0022-0663.84.3.261

Ananta, A., Arifin, E. N., \& Bachtiar. (2008). Chinese Indonesians in Indonesia and the province of Riau archipelago: A demographic analysis. In L. Suryadinata (Ed.), Ethnic Chinese in contemporary Indonesia. Singapore: Institute of Southeast Asian Studies and Chinese Heritage Centre.

Anderson, N. H., \& Butzin, C. A. (1974). Performance = motivation x ability: An integration-theoretical analysis. Journal of Personality and Social Psychology, 30, 598-604. http://dx.doi.org/10.1037/h0037447

Archer, J. (1994). Achievement goals as a measure of motivation in university students. Contemporary Educational Psychology, 19, 430-446. http://dx.doi.org/10.1006/ceps.1994.1031

Ashmore, R. D., Deaux, K., \& McLaughlin-Volpe, T. (2004). An organizing framework for collective identity: Articulation and significance of multidimensionality. Psychological Bulletin, 130(1), 80-114. http://dx.doi.org/10.1037/0033-2909.130.1.80

Banskton, C. L., \& Zhou, M. (1997). The social adjustment of Vietnamese American adolescents: Evidence for a segmented assimilation approach. Social Science Quaterly, 78, 508-523.

Blackburn, S. (2004). Women and the State in modern Indonesia. Cambridge: Cambridge University Press. http://dx.doi.org/10.1017/CBO9780511492198

Blackburn, S. (2009). Perempuan dan negara dalam era Indonesia moderen. [Women and the State in modern Indonesia.] Jakarta: Kalyanamitra.

Bong, M. (2001). Between- and within-domain relations of academic motivation among middle and high school students: Self-efficacy, task-value, and achievement goals. Journal of Educational Psychology, 93(1), 23-34. http://dx.doi.org/10.1037/0022-0663.93.1.23

Buchanan, T., \& Selmon, N. (2008). Race and gender differences in self-efficacy: Assesing the role of gender attitudes and family background. Sex Roles, 58, 822-836. http://dx.doi.org/10.1007/s11199-008-9389-3 
Butler, R. (1989). Interest in the task and interest in peers' work in competitive and non-competitive condition: A developmental study. Child Development, 60, 562-570. http://dx.doi.org/10.2307/1130722

Cialdini, R. B., Wosinska, W., Wabul, A. J., Whetstone-Dion, R., \& Heszen, I. (1998). When social role salience leads to social role rejection: Modest self-presentation among women and men in two cultures. Personality and Social Psychology Bulletin, 24, 473-481. http://dx.doi.org/10.1177/0146167298245003

Clark, M. (2010). Maskulinitas culture, gender and politics in Indonesia. Caulfield: Monash University Press.

Cohen, A. B., Siegel, J. I., \& Roezin, P. (2003). Faith versus practice: Different bases for religiosity judgments by Jews and Protestants. European Journal of Social Psychology, 75, 709-742.

Coomaraswammy, R. (1999). Integration of the human rights of women and the gender perspective: Violence against women (mission to Indonesia and East Timor on the issue of violence against women). Geneva: United Nations High Commisioner for Human Rights.

Dedert, E. A., Studts, J. L., Weissbecker, I., Salmon, P. G., Banis, P. L., \& Sephton, S. E. (2004). Religiosity may help preserve the cortisol rhytm in women with stress-related illness. International Journal of Psychiatry in Medicine, 34(1), 61-77. http://dx.doi.org/10.2190/2Y72-6H80-BW93-U0T6

Diener, C. I., \& Dweck, C. S. (1978). An analysis of learned helplessness: Continous changes in performance, strategy, and achievement cognitions following failure. Journal of Personality and Social Psychology, 36, 451-462. http://dx.doi.org/10.1037/0022-3514.36.5.451

Downson, M., \& McInerney, D. M. (2001). Psychological parameter of students' social and work avoidance goals: A qualitative investigation. Journal of Educational Psychology, 93(1), 35-42. http://dx.doi.org/10.1037/0022-0663.93.1.35

Dweck, C. S. (1975). The role of expectation and attributions in the alleviation of learned helplessness. Journal of Personality and Social Psychology, 31, 674-685. http://dx.doi.org/10.1037/h0077149

Dweck, C. S., Goetz, T. E., \& Strauss, N. (1980). Sex differences in learned helplessness: (IV) An experimental and naturalistic study of failure generalization and its mediators. Journal of Personality and Social Psychology, 38, 441-452. http://dx.doi.org/10.1037/0022-3514.38.3.441

Dweck, C. S. (1986). Motivational processes affecting learning. American Psychologist, 41, 1040-1048. http://dx.doi.org/10.1037/0003-066X.41.10.1040

Dweck, C. S., \& Leggett, E. (1988). Social-cognitive approach to motivation and personality. Psychological Review, 95(2), 256-273. http://dx.doi.org/10.1037/0033-295X.95.2.256

Elliot, A. J., \& Harackiewicz, J. M. (1996). Approach and avoidance achievement goals and intrinsic motivation: A motivational analysis. Journal of Personality and Social Psychology, 54(1), 5-12.

Elliot, A. J. (1999). Approach and avoidance in motivation and achievement goals. Educational Psychologist, 34, 149-169. http://dx.doi.org/10.1207/s15326985ep3403_3

English, T., \& Chen, S. (2007). Culture and self-concept stability: Consistency across and within contexts among Asian Americans and European Americans. Journal of Personality and Social Psychology, 93, 478-490. http://dx.doi.org/10.1037/0022-3514.93.3.478

Fredricks, J. A., \& Eccles, J. S. (2002). Children's competence and value beliefs from childhool through adolescence: Growth trajectories in two male-sex-typed domains. Developmental Psychology, 38, 519-533. http://dx.doi.org/10.1037/0012-1649.38.4.519

Hackett, G., Betz, N. E., Casas, J. M., \& Rocha-Singh, I. A. (1992). Gender, ethnicity, and social cognitive factors predicting the academic achievement of students in engineering. Journal of Counselling Psychology, 39(47), 527-538. http://dx.doi.org/10.1037/0022-0167.39.4.527

Harackiewicz, J. M., Durik, A. M., Barron, K. E., Linnenbrink-Garcia, L., \& Tauer, J. M. . (2008). The role of achievement goals in the development of interest: Reciprocal relations between achievement goals, interests, and performance. Journal of Educational Psychology, 100(1), 105-122. http://dx.doi.org/10.1037/0022-0663.100.1.105

Hong, Y. Y., Chiu, C., Dweck, C. S., Derrick, M. S., \& Wan, W. (1999). Implicit theories, attributions, and coping: A meaning system approach. Journal of Personality and Social Psychology, 77(3), 588-599. $\mathrm{http}: / / \mathrm{dx}$.doi.org/10.1037/0022-3514.77.3.588 
Jacobs, J. E., Lanza, S., Osgood, D. W., Eccles, J. S., \& Wigfield, A. (2002). Changes in children's self-competence and values: gender and domain differences across grades one through twelve. Child Development, 73(2), 509-527. http://dx.doi.org/10.1111/1467-8624.00421

Jusuf, E. I., Timbul, H., Gultom, O., \& Frishka, S. (2008). Kerusuhan Mei 1998: Fakta, data, dan analisa. May riot 1998: Facts, data, and analysis. Jakarta: Solidaritas Nusa Bangsa \& Asosiasi Penasihat Hukum dan Asasi Manusia Indonesia.

Koenig, H. G., Meador, K., \& Parkerson, G. (1997). Religion index for psychiatric research: A 5-item measure for use in health outcome studies. American Journal of Psychiatry, 154, 885-886.

Mackie, D. M., \& \& Smith, E. R. (1998). Intergroup relations: Insights from a theoretically integrative approach. Psychological Review, 105, 499-529. http://dx.doi.org/10.1037/0033-295X.105.3.499

Meece, J., Blumenfeld, P. C., \& Hoyle, R. H. (1988). Students' goal orientations and cognitive engagement in classroom activities. Journal of Educational Psychology, 80(4), 514-523. http://dx.doi.org/10.1037/0022-0663.80.4.514

Meece, J., \& Holt, K. (1993). A pattern analysis of students' achievement goals. Journal of Educational Psychology, 85(4), 582-590. http://dx.doi.org/10.1037/0022-0663.85.4.582

Midgley, C., Maehr, M. L., Hruda, L. Z., Anderman, E., Anderman, L., Freeman, K. E., Gheen, M., Kaplan, A., Kumar, R., Middleton, M. J., Nelson, J., Roeser, R., \& Urdan, T. (2000). Manual for the pattern of adaptive learning scales. Ann Arbor, MI: University of Michigan.

Ong, H. H. (2005). Riwayat Tionghoa Peranakan di Jawa. History of Peranakan Chinese in Java. Jakarta: Komunitas Bambu.

Oyserman, D., Harrison, K., \& Bybee, D. (2001). Can racial identity be promotive of academic efficacy? International Journal of Behavioural Department, 25, 397-385.

Peck, S. C., Brodish, A. B., Malanchuk, O., \& Eccles, J. (2008). Dimension of racial/ethnic identity. University of Michigan. Ann Arbor, MI.

Pintrich, P., \& Schrauben, B. (1992). Students' motivational beliefs and their cognitive engagement in academic tasks. In D. Schunk, \& Meece, J. (Ed.), Students' perception in the classroom: Causes and consequences. Hillsdale, NJ: Erlbaum.

Pintrich, P. R., \& Schunk, D. H. (2002). Motivation in education: Theory, research, and application (2 ed.). Columbus, OH: Merrill-Prentice.

Smart, N. (1998). The world's religions. New York: Cambridge University Press.

Steele, C. M. \& Aronson., J. (1995). Stereotype threat and the intellectual performance of African Americans Journal of Personality and Social Psychology, 69, 797-811.

Sutantoputri, N. W., \& Watt, H. M. G. (2012). Attribution and motivation: A cultural study among Indonesian university students. International Journal of Higher Education, 1(2), 118-129. doi: 10.5430/ijhe.v1n2p118Triandis, H. C. (1995). Individualism and collectivism. Boulder, CO: Westview Press.

Triandis, H. C., \& Geldfand, M. J. (1998). Converging measurement of horizontal and vertical individualism and collectivism. Journal of Personality and Social Psychology, 74, 118-128. http://dx.doi.org/10.1037/0022-3514.74.1.118

Urdan, T., \& Maehr, M. L. (1995). Beyond a two-goal theory of motivation and achievement: A case for social goals. Review of Educational Research, 65, 213-243.

Urdan, T., \& Midgley, C. (2001). Academic self-handicapping: What we know, what more there is to learn. Educational Psychology Review, 13(2), 115-138. http://dx.doi.org/10.1023/A:1009061303214

Urdan, T. (2004). Predictors of academic self-handicapping and achievement: Examining achievement goals, classroom goal structures, and culture. Journal of Educational Psychology, 96(2), 251-264. http://dx.doi.org/10.1037/0022-0663.96.2.251

Venkatachari, K. K. A. (1996). Transmission and transformation of rituals. In R. B. Williams (Ed.), A sacred thread: Modern transmission of Hindu traditions in India and abroad (pp. 177-190). New York: Colombia University Press. 
Watt, H. M. G. (2004). Development of adolescents' self-perceptions, values, and task perceptions according to gender and domain in 7th through 11th grade Australian students. Child Development, 75, 1556-1574. http://dx.doi.org/10.1111/j.1467-8624.2004.00757.x

Weiner, B. (1979). A theory of motivation for some classroom experience. Journal of Educational Psychology, 71, 3-25. http://dx.doi.org/10.1037/0022-0663.71.1.3

Weiner, B. (1985). An attributional theory of achievement motivation and emotion. Psychological Review, 92(4), 548-573. http://dx.doi.org/10.1037/0033-295X.92.4.548

Witkow, M. R., \& Fuligni, A. J. (2007). Achievement goals and daily school experiences among adolescents with Asian, Latino, and European American backgrounds. Journal of Educational Psychology, 99(3), 584-596. http://dx.doi.org/10.1037/0022-0663.99.3.584

Wolters, C. A., Yu, S. L., \& Pintrich, P. R. (1996). The relation between goal orientation and students' motivational beliefs and self-regulated learning. Learning and individual differences, 8, 211-238. http://dx.doi.org/10.1016/S1041-6080(96)90015-1

Woodrow, L., \& Chapman, E. (2002). Assessing the motivational goal orientations of international English for Academic Purposes (EAP) students. Current Research in Social Psychology, 7(15), 257-274. 
Table 1. Sample Items

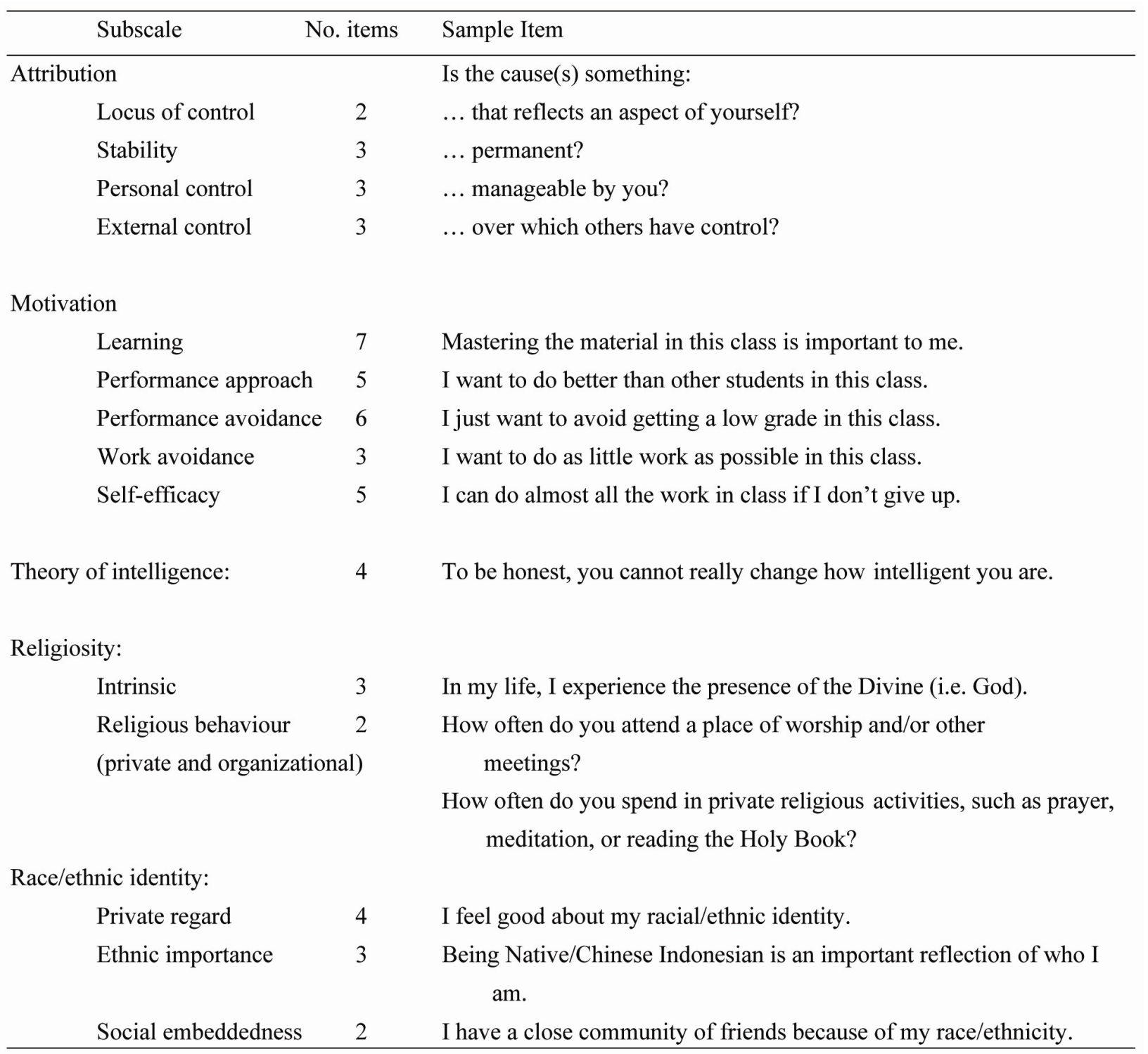

